\title{
Quality Traits of Longissimus thoracis and lumborum and Gluteus medium Muscles from Cull Dairy Holstein-Friesian Cows
}

\author{
Carlos Santos ${ }^{1}$, Carlos Moniz ${ }^{2}$, Cristina Roseiro ${ }^{1}$, Vera Medeiros ${ }^{2}$, Isabel Afonso ${ }^{2}$, Marina Tavares ${ }^{2}$, Manuel A. \\ Dias $^{3} \&$ Duarte J. B. da Ponte ${ }^{4}$ \\ ${ }^{1}$ Instituto Nacional de Investigação Agrária e Veterinária, I.P., Unidade Estratégica de Investigação e Serviços de \\ Tecnologia e Segurança Alimentar, Campus do IAPMEI, Edifício S, Estrada do Paço do Lumiar, 22, 1649-038 \\ Lisboa, Portugal \\ ${ }^{2}$ Instituto de Inovação Tecnológica dos Açores, Estrada de S. Gonçalo, 9504-540, Ponta Delgada, Açores, \\ Portugal \\ ${ }^{3}$ Alicontrol - Tecnologia e Controlo de Alimentos, Lda., Rua Fernando Vaz, Lote 26-B, 1750-108 Lisboa, \\ Portugal \\ ${ }^{4}$ Universidade dos Açores, Departamento de Ciências Tecnológicas e Desenvolvimento, Rua Mãe Deus, \\ 9500-321 Ponta Delgada, Açores, Portugal
}

Correspondence: Carlos Santos, Instituto Nacional de Investigação Agrária e Veterinária, I.P. Unidade Estratégica de Investigação e Serviços de Tecnologia e Segurança Alimentar. Campus do IAPMEI, Edifício S, Estrada do Paço do Lumiar, 22, 1649-038 Lisboa. Portugal. Tel: 351-217-127-108. E-mail: carlos.santos@iniav.pt

Received: July 13, 2015 Accepted: October 1, 2015 Online Published: November 12, 2015

doi:10.5539/jfr.v4n6p82 URL: http://dx.doi.org/10.5539/jfr.v4n6p82

\begin{abstract}
Longissimus thoracis and lumborum (LTL) and Gluteus medius (Gm) muscles of culled dairy cows, differing in production status (Ps) at slaughter and carcass weight were assessed for intramuscular fat and myoglobin, color, shear force (SF) and sensorial characteristics, after being aged for 2, 7, 14, 28 and 42 days. Meat from dried-off cows was lighter, redder and had higher yellowness and chroma $(P<0.05)$ than lactating cows. Meat of finished fed cows improved in color in relation to counterparts directly slaughtered, but not significantly. Color parameters increased with aging time and the mean values of LTL and Gm significantly differed mostly among lactating cows. SF of meat was affected by aging time, muscle type, Ps and by their respective interactions $(P<$ $0.001)$, with a greater impact in LTL muscle. Meat from LTL muscle of dried-off cows had lower SF $(47.30 \mathrm{~N})$ than that of lactating cows $(65.61 \mathrm{~N})(P<0.05)$, but such differences were not significant for Gm muscle. Meat tenderness of finished fed cows was higher than counterparts not finished $(P>0.05)$. Main effects and the results from their interactions were significant for all sensorial attributes $(P<0.001)$.
\end{abstract}

Keywords: aging, cull dairy cows, dried-off, finishing feeding, lactating

\section{Introduction}

A large number of adult Holstein-Friesian cows, quite heterogeneous in body condition and production status before slaughter, are culled every year from the dairy production sector in Azores, representing about $49 \%$ of the slaughtering in the island. Aside psoas major and longissimus dorsi muscles, meat obtained from another anatomical locations is not considered by local stakeholders as deserving other end destination than grinding/mincing for hamburgers or similar meat products manufacture, which depreciates carcasses value and farmers revenue. Apparently no reasons exist for the lack consumers acceptability if good commercial appearance and consistent flavour and tenderness attributes were achieved with such meat, amounting to almost 1500 lean tones/year.

Red meat purchasing decision is determined by color more than any other quality trait, with discoloration in retail being perceived by consumers as an indicator of freshness and wholesomeness (Mancini \& Hunt, 2005; Singh, Wani, Saengerlaub, \& Langowski, 2011), while a minimum of tenderness is rather needed for a good appreciation of flavour and a positive overall acceptability. Both attributes are influenced by aging conditions (Koohmaraie, 1996; Sentandreu, Coulis, \& Ouali, 2002).

Since changes in muscle fiber size and metabolic type as well as an increase in protein catabolism were detected 
in lactating cows (Chibiza, Gozh, Van Kessel, Olkowski, \& Mutsvangwa, 2008; Gray, 2008), their carcasses lean meat yield and meat quality profile (Lee, Joo, \& Ryu, 2010; Wheeler, Cundiff, Koch, \& Crouse, 1996, Wheeler, Cundiff, Shackelford, \& Koohmaraie, 2005) can be affected when compared to dried-off counterparts. Otherwise,

dried-off cows fed a high-energy diet before slaughter showed increased rates of protein turnover. Such changes probably affect collagen solubility and myofibril fragmentation (improved tenderness) (Fishell, Aberle, Judge, \& Perry, 1985), promoting a better body condition and fatty state (eventual better price associated with carcass classification) (Cranwell, Unruh, Brethour, \& Simms, 1996; Franco, Bispo, González, Vázquez, \& Moreno, 2009.

The aim of the present study was to evaluate the variability in objective color, tenderness characteristics and sensorial attributes of meat from culled dairy cows, obtained from the Longissimus thoracis and lumborum (LTL) and Gluteus medius $(\mathrm{Gm})$ muscles, in relation to production status (dried-off vs. lactating) before slaughter, carcass weight and the influence of different aging periods (2, 7, 14, 28 and 42 days). The impact of a finishing feeding regimen, one month before slaughter, was also examined.

\section{Material and Methods}

\subsection{Animals}

Thirty two culled dairy cows reared at different farms under similar feeding regime, based on natural pasture or green silage and concentrate, were grouped according to their production status (lactating- 10 cows; dried-off 10 cows; dried-off finished fed before slaughter - 12 cows) as referred in Roseiro, Santos, Gonçalves, Moniz, Afonso, Tavares and da Ponte (2014). The drying condition was achieved by feeding cows only with straw and some water deprivation.

The dried-off cows finished fed for 1 month before slaughter (12 animals), apart the silage available "at libitum" were supplemented $\left(3 \mathrm{~kg}\right.$.day ${ }^{-1}$ during the first 2 weeks followed by $5 \mathrm{~kg}_{\text {.day }}{ }^{-1}$ up to the end of the testing period) with a commercial concentrate (crude protein: $14.0 \%$; fat content: $5.0 \%$; ashes: $5.6 \%$; cellulose: $8.3 \%$ ) added of vitamin A (6000 UI), vitamin D3 (2000 UI), vitamin E (10 mg. $\left.\mathrm{kg}^{-1}\right)$ and trace elements. Cows were slaughtered conventionally at different days in a commercial abattoir at S. Miguel, Azores (Table 1), following identical technical peri-mortem procedures (transport duration, animal density in vehicle, lairage time, electrical stimulation and chilling conditions) to mitigate any influence associate to the slaughter day. Carcasses were electrically stimulated (low voltage current) for about 1 minute during the bleeding stage, about 5 minutes after stunning (captive bolt). After dressing, weighting and classification (conformation and fatness), according to Regulation (EC) $\mathrm{N}^{\circ} 103 / 2006$ of the European Commission, the carcass sides were cooled down at $0-1{ }^{\circ} \mathrm{C}$ with a ventilation rate of $3-4 \mathrm{~m} / \mathrm{s}$ for about 1 hour and then chilled at $2^{\circ} \mathrm{C}$ and $0.5-1 \mathrm{~m} / \mathrm{s}$ ventilation rate, for the next 48 hours. At this point, the LTL muscle and the whole Gm muscle were taken from the left hindquarter (quarters separated at the $12^{\text {th }}$ rib level) and sent, under refrigeration, to the laboratory for analysis.

Table 1. Age and carcass weight mean \pm standard error (SE), minimum and maximum values of cull dairy cows evaluated within each production status group

\begin{tabular}{llcc}
\hline & & Age (years) & Carcass weight $(\mathrm{kg})$ \\
\hline \multirow{3}{*}{ Dried-off $\quad(\mathrm{n}=10)$} & Mean \pm SE & $6.6 \pm 1.2$ & $288.0 \pm 20.6$ \\
& Min & 2.1 & 218 \\
& Max & 11.8 & 431 \\
\hline \multirow{3}{*}{ Lactating $(\mathrm{n}=10)$} & Mean \pm SE & $6.4 \pm 0.8$ & $273.7 \pm 20.6$ \\
& Min & 2.3 & 180 \\
& Max & 9.9 & 371 \\
\hline \multirow{3}{*}{ Dried-off finishing fed $(\mathrm{n}=12)$} & Mean \pm SE & $7.9 \pm 0.5$ & $323.0 \pm 11.7$ \\
& Min & 6.0 & 254 \\
& Max & 10.7 & 397 \\
\hline
\end{tabular}

$\overline{\mathrm{SE}}=$ Standard error. 


\subsection{Sampling and Analytical Methods}

After separating all visible fat and connective tissue, the LTL and Gm pieces were cut into 6 sub-samples (about $6 \mathrm{~cm}$ thick), packed in vacuum COEX PA/PE - 20/70 plastic bags (Plásticos Macar, S. Tirso, Portugal permeability to oxygen: $50 \mathrm{~cm}^{3} / \mathrm{m}^{2}$.day.bar at $23^{\circ} \mathrm{C}$ and $0 \%$ of relative humidity and stored at $2{ }^{\circ} \mathrm{C}$ ) and randomly assigned to each aging time (2, 7, 14, 28 and 42 days).

Muscle $\mathrm{pH}$ between vertebrae L1 and L2 (LTL muscle) and around the central portion of the Gm muscle was measured using a portable $\mathrm{pH}$ meter (Crison 507, 08328 Alella, Spain) equipped with a glass probe (Ingold, lot406-M6-DKX) for penetration. Samples with a final pH higher than 6.0, were not used in the current study.

Myoglobin and intramuscular fat (IMF) contents were determined in duplicate according to the methods described by Hornsey (1956) and Folch, Lees \& Stanley (1957), respectively.

For color measurements, a portable colorimeter Minolta (CR-300 Osaka, Japan) in the CIELAB space (Lightness, $\mathrm{L}^{*}$; redness, $\mathrm{a}^{*}$; yellowness, $\mathrm{b}^{*}$ ) was used with head settings: pulsed xenon arc lamp, angle of $0^{\circ}$ viewing angle geometry and aperture size of $8 \mathrm{~mm}$. After opening the vacuum packages, the samples were evaluated every 10 minutes for 1 hour of blooming, with the results being the mean of triplicates. Values determined after 60 minutes of blooming were used to compare the color behaviour on samples with the different conditions studied, under the aging times assayed.

Regarding shear force evaluation, samples with about $2.5 \mathrm{~cm}$ of thickness were cooked in a water bath at $80^{\circ} \mathrm{C}$ until getting $75^{\circ} \mathrm{C}$ in the critical point, then they were cooled down in ice water for about 30 minutes and stored under vacuum in a refrigerator $\left(0-2^{\circ} \mathrm{C}\right)$. The cores $(1 \times 1 \times 4 / 5 \mathrm{~cm})$ for Warner-Blatzer $(\mathrm{WB})$ shear tests $(500 \mathrm{~kg}$ cell) were cut parallel to the muscle fibers direction and held about 1 hour at room temperature for equalization before analysis. Afterwards, they were completely cut by the shear blade (triangular slot cutting edge, of $1 \mathrm{~mm}$ of thickness), perpendicular to the fibers, at a crosshead speed of $1 \mathrm{~mm} / \mathrm{s}$ (Instron 4501 model, H3279, England). Each mean value was obtained from between six and ten recordings and expressed as Newtons.

Sub-samples for sensory evaluation (steaks around $3.0 \mathrm{~cm}$ thick) were currently held frozen $\left(-20^{\circ} \mathrm{C}\right)$ until analysis. They were thawed under chilling $\left(0-2^{\circ} \mathrm{C}\right)$ over-night and then grilled (surface temperature around $200^{\circ} \mathrm{C}$ ) simultaneously on both surfaces (UNOX - Spido Cook, mod: XP010P, Padova, Italy), up to an internal temperature of $70^{\circ} \mathrm{C}$, which was monitored through a thermocouple $(10 \mathrm{~cm}$ spear point, T-type $)$ attached to an electrical thermometer (ELLAB CTD 85, Copenhagen, Denmark). After discarding the 2-3 mm outer portion of the steak directly in contact with the grill surface, cubes (as much as possible close to $1 \mathrm{~cm}^{3}$ ) from cores obtained from each steak were randomly presented to the trained 8-member panel, so that all panelists received and evaluated all samples (randomized complete-block design). Cubes were placed in covered Petri glass containers in a water bath $\left(40^{\circ} \mathrm{C}\right)$ for temperature equilibration before panelist's evaluation. Panelists assayed 5 samples per sitting (maximum) along approximately 1.5 years of working sessions promoted regularly once a week, exceptionally twice a week. Sensory attributes (tenderness, juiciness and flavor) were scored on an 8-point scale (1-low in intensity; 8-extremely high in intensity). A panel rating detection was considered to be the average of the independent scores from the 8 panel members. Basically, panelists were trained in samples scoring by eating cow meat obtained from animals differing in age before slaughter and matured shortly or for extended periods of time (tenderness and flavor intensity) as well as by evaluating samples grilled under distinct intensities (juiciness).

\subsection{Statistical Analysis}

To determine the effect of production status (PS), muscle (M) and aging time (AT) in shear force, color parameters and sensory attributes variations, a 3-way ANOVA was carried out using JMP statistical software (Version 9.0.1, SAS Institute, Inc., Cary, NC, USA, 2010). Once measurements in different muscles of the same animal are not independent observations, muscle type was treated as repeated measure within each animal. The production status (lactating, dried-off and dried-off with flushing), muscle (Gm and LTL) and aging time (2, 7 , 14, 28 and 42 days) were considered fixed effects. Carcass weight was considered as covariate in the model, but it was removed since no significant related effects were found.

The following final linear mixed model was used: $y=\mu+P s+A t+M+P s x A t+P s x M+A t x M+P s x A t x M+e$. In the model, $\mathrm{y}$ is the dependent variable analysed, $\mu$ the mean value common to all observations, Ps the fixed effects of production status, At the fixed effects of aging time and $M$ the fixed effects of muscle. PsxAt, PsxM, AtxM and PsxAtxM represent the interactions between factors and e the error term. When significantly affected $(P<0.05)$, least square means were compared using the Tukey HSD post hoc test. Concerning the variation in intramuscular fat and myoglobin contents, the muscle type and PS were evaluated as fixed effects through a 
2-way ANOVA, being muscle type treated as repeated measure within each animal.

\section{Results and Discussion}

\subsection{Fat deposition under the Finishing Feeding Regime}

The meat yield classification pattern of carcasses from dried-off cows sent directly to slaughter $(\mathrm{P}-60 \% ; \mathrm{O}-$ $40 \%$ ) was similar to that of finished fed population ( $\mathrm{P}-70 \%$; $\mathrm{O}-30 \%)$, but the carcasses fatness score within this last Ps improved considerably (class $3-70 \%$ and class $2-30 \%$ ) in relation to the former Ps (class $3-30 \%$ and class $2-70 \%$ ). The live weight/body condition at which high-grain finishing diet is initiated seems to influence the performance on partitioning of diet surplus energy between subcutaneous and inter-muscular adipose depots (Schaefer, 2005). In addition, Nour, Thonney, Stouffer \& White (1983) found that carcass weight accounted for $57 \%$ of the variation in muscle marbling score in Holsteins, indicating an increase of 2.9 units for each increase of $100 \mathrm{~kg}$ in carcass weight. The improvement in carcasses fatness of finished fed dried-off cows did not correspond to a general higher mean IMF (Table 2). Comparatively to unfinished dried-off cows, the Gm muscle showed increased IMF levels $(+23.6 \%)$, but the LTL muscle, on the contrary, presented a slightly lower mean value (-4.3\%). Nonetheless, differences in both muscles among the referred Ps groups were not significant $(P=0.229)$. Within the lactating population the IMF overall mean percentage $(2.0 \%)$ was significantly lower $(P$ $=0.046)$ than in dried-off counterparts $(3.11 \%$ vs. $3.41 \%)$ (Table 2$)$.

The influence of the finishing regime based on concentrates referred by Matulis, McKeith, Faulkner, Berger \& George (1987), Price \& Berg (1981) and Vestergaard, Madsen, Bligaard, Bredahl, Rasmussen \& Andersen (2007) was not totally confirmed in our study but the present results are in accordance with those reported by Franco et al. (2009), who also did not find significant differences in IMF of LTL muscles from 1 month finishing fed Holstein-Fresian cull cows in relation to counterparts directly slaughtered. Discrepancies among studies might be due to differences among the tested populations, concerning age (Graham \& Price, 1982; Malterre, Robelin, Agabriel \& Bordes, 1989; Sawyer, Mathis \& Davis, 2004), body condition and fatness (Graham \& Price, 1982), which determine the production performance of animals under finishing regime. Since heritability of marbling is high (Dikeman, Pollak, Zhang, Moser, Gill, \& Dressler, 2005), strategies for marbling enhancement in mature Holstein cows have been fruitless (Schaefer, 2005).

Table 2. Impact of production status and muscle type on myoglobin and intramuscular fat (IMF) mean contents of meat (Gm and LTL muscles) of cull dairy cows

\begin{tabular}{|c|c|c|c|c|c|}
\hline & & $\begin{array}{l}\text { Myglobin } \\
\left(\mathrm{mg} \cdot \mathrm{g}^{-1}\right)\end{array}$ & $\begin{array}{c}\text { Ps overall } \\
\text { means }^{2}\end{array}$ & $\begin{array}{l}\text { IMF } \\
(\%)\end{array}$ & $\begin{array}{c}\text { Ps overall } \\
\text { means }^{2}\end{array}$ \\
\hline \multirow[t]{2}{*}{ Lactating } & $\mathrm{Gm}$ & $7.16(0.35)$ & \multirow{2}{*}{$6.90(0.27)$} & $1.73(0.26)$ & \multirow{2}{*}{$2.00^{\mathrm{b}}(0.27)$} \\
\hline & LTL & $6.63(0.42)$ & & $2.27(0.48)$ & \\
\hline \multirow[t]{2}{*}{ Dried-off } & $\mathrm{Gm}$ & $7.71(0.58)$ & \multirow{2}{*}{$7.18(0.37)$} & $2.46(0.33)$ & \multirow{2}{*}{$3.11^{\mathrm{a}}(0.39)$} \\
\hline & LTL & $6.65(0.42)$ & & $3.76(0.67)$ & \\
\hline \multirow[t]{2}{*}{ Dried-off finished fed } & $\mathrm{Gm}$ & $7.69(0.49)$ & \multirow{2}{*}{$7.25(0.30)$} & $3.22(0.28)$ & \multirow{2}{*}{$3.41^{\mathrm{a}}(0.17)$} \\
\hline & LTL & $6.82(0.68)$ & & $3.60(0.52)$ & \\
\hline \multirow[t]{2}{*}{ M overall mean ${ }^{1}$} & $\mathrm{Gm}$ & $7.52^{\mathrm{a}}(0.27)$ & & $2.47^{\mathrm{b}}(0.20)$ & \\
\hline & LTL & $6.70^{\mathrm{b}}(0.22)$ & & $3.2^{\mathrm{a}}(0.33)$ & \\
\hline \multirow[t]{3}{*}{$P$ values } & Ps & 0.817 & & 0.046 & \\
\hline & $M$ & $<0.001$ & & 0.003 & \\
\hline & $P S * M$ & 0.495 & & 0.229 & \\
\hline
\end{tabular}

${ }^{1}$ M overall mean $=$ Mean values for each muscle irrespective of the production status condition.

${ }^{2}$ Ps overall mean $=$ Mean values for each Production status condition irrespective of the muscle type.

Within each trait, overall means $(M)$ and overall means $(P S)$ with different letters are significantly different.

Standard errors are within brackets. 


\subsection{Color and Blooming}

Factors considered in the present study, single or as a result of $\mathrm{M}^{*} \mathrm{Ps}$ and Ps*At interactions, significantly affected the meat color parameters (excepting the Ps*At effect in $\mathrm{L}^{*}$ value, $P=0.28$ ). The impact from $\mathrm{M}^{*} \mathrm{At}$ only tended to be expressed in redness $(P=0.064)$, yellowness $(P=0.045)$ and chroma $(P=0.058)$ and missed any influence on meat luminosity $(P=0.152)$. The meat color parameters were not significantly affected by the 3 factors interaction ( $\left.\mathrm{Ps}^{*} \mathrm{At} * \mathrm{M}\right)$ (Table 3). The meat of lactating cows obtained from the LTL muscle was darker (35.63) and had lower redness (20.37), yellowness $(8.36)$ and color intensity (chroma $=22.04)$ than that of dried-off counterparts $(\mathrm{P}<0.05)$, which did differ significantly. The color parameters of meat from $\mathrm{Gm}$ muscle were not significantly affected by differences in Ps. The meat of cows flushing finished for a month before slaughter, in general, showed slightly higher color parameters overall mean values than that of dried-off cows sent directly to slaughter $(\mathrm{P}>0.05)$. Apart from the muscle type, such differences were more evident at the early aging stage (2 days). Whatever the muscle type and the animal production status, meat of culled dairy cows turned lighter, redder and with greater yellowness and color intensity with aging time elapsed, but such increase in mean values was around 3 units ( $\mathrm{L}^{*}$ and $\mathrm{b}^{*}$ ) and 4 units (a* and chroma), and mostly occurred up to 7 days period. Our results corroborate those reported by Minchin, Buckley, Kenny, Monahan, Shalloo and O'Donovan, (2009) but disagree with the findings of Muir, Smith, Wallace, Cruickshank and Smith (1998) who showed a significant effect of short-term concentrate feeding on $\mathrm{L}^{*}$ and $\mathrm{a}^{*}$ values. The myoglobin overall mean content in Gm and LTL muscles $(7.52 \mathrm{mg} / \mathrm{g}$ and $6.70 \mathrm{mg} / \mathrm{g}$, respectively) appeared significantly different $(P<0.05)$ (Table 2), which probably may be related to their different fibers contractile profiles (Roseiro et al., 2014). The Ps and Ps*M interaction effects on muscles myoglobin were not significant.

Regarding $L^{*}, a^{*}$ and chroma values at day 2 of aging, the LTL muscle of the finished fed dried-off cows was lighter, redder and had higher color intensity than that of dried-off cows directly sent to slaughter. By extending the aging period, those differences were reduced or even inverted for the benefit of the later Ps group. In spite of aging period, the LTL muscle from lactating cows appeared slightly darker, with lower redness and lower color intensity then the other two groups.

Despite the lack of significance of the PS*AT effect on color characteristics of Gm muscle, the respective mean values again confirmed the finished cows as the group having the highest values, comparatively to the other two PS conditions $(P>0.05)$ (Table 3$)$. The $\mathrm{a}^{*}, \mathrm{~b}^{*}$ and chroma mean values on Gm muscle, similarly to the evolution referred for the LTL muscle, also increased significantly with aging time for all Ps groups, with such increase mostly occurring within lactating and dried-off cows at day 7, comparatively to the finished fed population (day 14).

Considering the microbial counts (data not shown), the improvements on $\mathrm{a}^{*}$ and chroma mean values from day 28 to day 42 on meat of finished fed cows were not expected. However, this finding may be related to a greater intrinsic stability of the pigment redox in this meat (Bekhit, Geesink, Ilian, Morton, \& Bickerstaffe, 2003; Mancini, Hunt, Kim, \& Lawrence, 2004), particularly a higher level of antioxidant components (Tang, Faustman, Lee, \& Hoagland, 2003), such as creatine, anserine and Q10 concentrations (Roseiro et al., 2014). Yet, the greater oxidative potential prevailing in the $\mathrm{Gm}$ muscle, which would decrease lactate production while increasing pyruvate oxidation within mitochondria, and the time necessary to muscle exhaustion (Vestergaard, Oksberg, \& Henckel, 2000), may result here in less protein denaturation during rigor onset with the consequent impact on light incidence scattering (Bruce, Stark, \& Beilken, 2004).

Experiments with dried-off beef (Cranwell et al., 1996; Miller, Cross, Crouse, \& Jenkins, 1987) and dairy cull cows (Muir et al., 1998; Vestergaard et al., 2007) established that the high-energy finishing feeding brought about lighter and redder meat, with the former characteristic being attributed to increased marbling scores.

An increased IMF content was also obtained in our study but the color attributes seem to depend on the duration of the feeding regime, muscle type and aging period implemented.

Using the same genetic, Franco et al. (2009) found the meat of culled cows finished fed for 28 days darker $(P>$ $0.05)$ and redder $(P<0.05)$ than controls. When the finishing period was extended up to 2 months, those authors reported that the meat was lighter but less red than that of cows finished fed for 1 month $(P<0.05)$ and not significantly different from the controls. This effect was not consistent with the diet.

None withstanding the production status of cows before slaughter and the muscle type, meat expressed almost its total blooming capacity 30 minutes after the vacuum package opening, for any of the aging periods assayed. The $\mathrm{L}^{*}$ and $\mathrm{a}^{*}$ mean values achieved along the blooming process increased significantly with the aging time $(P<$ 0.001). (Figure 1a and 1b). 
Table 3. Influence of production status, muscle type and aging time on shear force and color parameters (measured after 60 minutes of blooming) of meat (Gm and LTL muscles) of cull dairy cows

\begin{tabular}{|c|c|c|c|c|c|c|c|c|c|c|c|c|c|c|c|c|}
\hline & \multirow[b]{2}{*}{$\begin{array}{l}\text { Aging } \\
\text { time }\end{array}$} & \multicolumn{3}{|c|}{$\mathrm{Gm}$} & \multicolumn{3}{|c|}{ LTL } & \multirow[b]{2}{*}{$\begin{array}{l}\text { Overall mean } \\
(A t)\end{array}$} & \multirow[b]{2}{*}{ SE } & \multicolumn{7}{|l|}{$P$ values } \\
\hline & & Lactating & Dried-off & $\begin{array}{c}\text { Flushin } \\
\mathrm{g}\end{array}$ & Lactating & Dried-off & Flushing & & & Ps & At & M & Ps*At & $\mathrm{M}^{*} \mathrm{Ps}$ & $\mathrm{M}^{*} \mathrm{At}$ & $\mathrm{Ps}^{*} \mathrm{At} * \mathrm{M}$ \\
\hline & 2 & 68.36 & 70.44 & 59.81 & 74.62 & 55.29 & 57.96 & $64.32^{a}$ & & & & & & & & \\
\hline & 7 & 64.31 & 58.21 & 53.66 & 63.72 & 52.57 & 49.15 & $57.13^{b}$ & & & & & & & & \\
\hline Shear force & 14 & 63.05 & 49.43 & 47.56 & 54.21 & 50.59 & 44.49 & $51.50^{b c}$ & 1.21 & $<0.001$ & $<0.001$ & 0.034 & 0.950 & $<0.001$ & 0.807 & 0.284 \\
\hline \multirow{2}{*}{ (N) } & 28 & 59.46 & 47.59 & 43.47 & 51.46 & 46.09 & 42.24 & $48.33^{c}$ & & & & & & & & \\
\hline & 42 & 58.88 & 45.27 & 46.52 & 52.14 & 48.51 & 39.29 & $48.47^{c}$ & & & & & & & & \\
\hline \multicolumn{2}{|c|}{ Overall mean $\left(F s^{*} M\right)$} & $56.43^{b}$ & $57.61^{a b}$ & $52.85^{\text {bo }}$ & $65.61^{a}$ & $47.30^{\text {cil }}$ & $43.90^{d}$ & & & & & & & & & \\
\hline \multirow{5}{*}{$L^{*}$} & 2 & 34.18 & 33.51 & 36.05 & 33.15 & 34.94 & 35.65 & $34.58^{d}$ & & & & & & & & \\
\hline & 7 & 35.20 & $3<.91$ & 35.38 & 35.44 & 36.64 & 35.80 & $35.56^{\mathrm{c}}$ & & & & & & & & \\
\hline & 14 & 35.69 & 36.48 & 36.50 & 36.46 & 37.44 & 36.81 & $36.56^{b}$ & 0.54 & $<0.001$ & $<0.001$ & $<0.001$ & 0.280 & $<0.001$ & 0.152 & 0.417 \\
\hline & 28 & 35.57 & 36.45 & 37.07 & 36.34 & 38.24 & 37.82 & $36.91^{a b}$ & & & & & & & & \\
\hline & 42 & 37.25 & 36.15 & 37.01 & 36.77 & 38.58 & 38.58 & $37.39^{a}$ & & & & & & & & \\
\hline \multicolumn{2}{|c|}{ Overall mean $\left(F s^{*} M\right)$} & $35.57^{b}$ & $3550^{b}$ & $36.40^{a b}$ & $35.63^{b}$ & $37.17^{a}$ & $36.93^{a}$ & & & & & & & & & \\
\hline \multirow{5}{*}{$\mathrm{a}^{*}$} & 2 & 18.42 & 18.52 & 20.77 & 17.61 & 19.09 & 20.12 & $19.09^{\circ}$ & & & & & & & & \\
\hline & 7 & 22.75 & 25.07 & 21.71 & 20.31 & 22.16 & 21.48 & $21.91^{b}$ & & & & & & & & \\
\hline & 14 & 23.88 & 23.04 & 23.15 & 21.42 & 22.67 & 22.43 & $22.77^{a}$ & 0.62 & $<0.001$ & $<0.001$ & $<0.001$ & $<0.001$ & $<0.001$ & 0.064 & 0.341 \\
\hline & 28 & 23.94 & $2\llcorner .46$ & 23.32 & 21.09 & 23.11 & 22.73 & $23.11^{a}$ & & & & & & & & \\
\hline & 42 & 22.75 & 23.11 & 24.80 & 21.44 & 22.75 & 23.83 & $23.11^{a}$ & & & & & & & & \\
\hline \multicolumn{2}{|c|}{ Overall mean $\left(F s^{*} M\right)$} & $22.35^{a b}$ & $22.44^{a b}$ & $22.75^{a}$ & $20.37^{c}$ & $21.96^{b}$ & $22.12^{a b}$ & & & & & & & & & \\
\hline \multirow{5}{*}{$b^{*}$} & 2 & 6.92 & 6.91 & 8.57 & 6.22 & 7.41 & 8.41 & $7.41^{c}$ & & & & & & & & \\
\hline & 7 & 10.03 & 9.84 & 8.92 & 8.48 & 9.87 & 9.20 & $9.39^{b}$ & & & & & & & & \\
\hline & 14 & 9.63 & 9.92 & 10.22 & 9.08 & 10.06 & 9.71 & $9.77^{b}$ & 0.44 & $<0.001$ & $<0.001$ & $<0.001$ & $<0.001$ & $<0.001$ & 0.045 & 0.193 \\
\hline & 28 & 10.93 & 11.06 & 10.42 & 9.03 & 10.26 & 10.19 & $10.32^{a}$ & & & & & & & & \\
\hline & 42 & 10.45 & 10.19 & 11.12 & 9.01 & 10.30 & 10.64 & $10.28^{\circ}$ & & & & & & & & \\
\hline \multicolumn{2}{|c|}{ Overall mean $\left(F^{*}{ }^{*} M\right)$} & $9.59^{a}$ & $9.58^{a}$ & $9.85^{a}$ & $8.36^{b}$ & $9.58^{a}$ & $9.63^{a}$ & & & & & & & & & \\
\hline \multirow{5}{*}{ Chroma } & 2 & 19.68 & 19.77 & 22.46 & 18.69 & 20.49 & 21.83 & $20.49^{c}$ & & & & & & & & \\
\hline & 7 & 24.88 & 25.10 & 23.48 & 22.02 & 24.27 & 23.37 & $23.85^{b}$ & & & & & & & & \\
\hline & 14 & 25.90 & 25.09 & 25.31 & 23.28 & 24.81 & 24.45 & $24.81^{a}$ & 0.72 & $<0.001$ & $<0.001$ & $<0.001$ & $<0.001$ & $<0.001$ & 0.058 & 0.391 \\
\hline & 28 & 26.32 & 26.85 & 25.57 & 22.95 & 25.29 & 24.92 & $25.31^{a}$ & & & & & & & & \\
\hline & 42 & 25.04 & 25.26 & 27.18 & 23.26 & 24.98 & 26.11 & $23.85^{a}$ & & & & & & & & \\
\hline \multicolumn{2}{|c|}{ Overall mean $\left(F s^{*} M\right)$} & $24.36^{a b}$ & $24.41^{a b}$ & $24.80^{a}$ & $22.04^{c}$ & $23.97^{b}$ & $24.13^{a b}$ & & & & & & & & & \\
\hline
\end{tabular}

Within each trait, overall means $\left(P s^{*} M\right)$ and overall means $(A t)$ with different letters are significantly different. SE - Standard error.

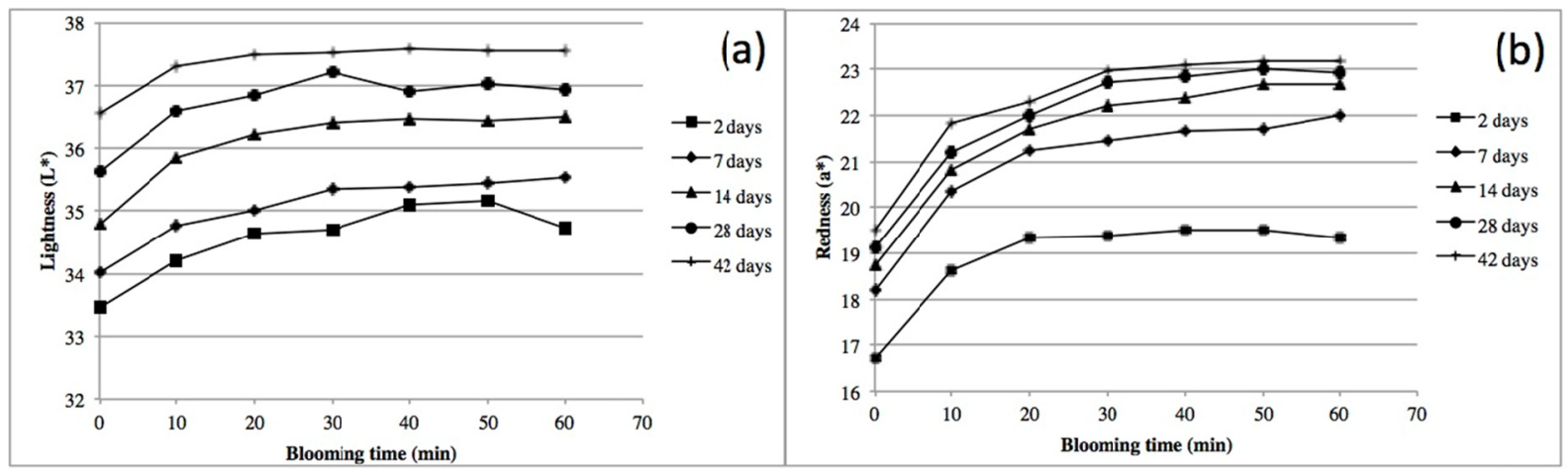

Figure 1. Evolution of $\mathrm{L}^{*}$ and $\mathrm{a}^{*}$ mean values along the aging process of meat (Gm and LTL average) for each blooming times studied

The blooming capacity evidenced by the LTL muscle was slightly more pronounced for the luminosity (approximately $+10.5 \%$ vs. $+6.5 \%$ ) while the improvement in redness was higher on Gm muscle (approximately $+22.4 \%$ vs. $+19.5 \%$ ) (data not shown). The decreasing functionality of muscle oxygen scavenging enzymes and consequently the level of $\mathrm{O}_{2}$ used by muscle respiratory chain could be the main feasible reason for this aging time effect on myoglobin chemistry (Mancini \& Hunt, 2005).

\subsection{Warner-Blatzer Shear Force}

The mean value of meat shear force from culled dairy cows was significantly affected by At, Ps and M*Ps interaction $(\mathrm{P}<0.001)$ and yet by the muscle type $(\mathrm{P}=0,034)$, whereas $\mathrm{Ps} * \mathrm{At}, \mathrm{M} * \mathrm{At}$ and $\mathrm{Ps}^{*} \mathrm{At} * \mathrm{M}$ interactions missed any significant impact on the results (Table 3 ). The meat from the LTL muscle of lactating cows significantly differed in the overall mean shear force $(65.61 \mathrm{~N})$ from dried-off counterparts directly slaughtered $(47.30 \mathrm{~N})$ or finished fed for 1 month before slaughter $(43.90 \mathrm{~N})$. Such influence was not seen in Gm muscle. Since the effect of Ps (dried-off vs. lactating) in cooked meat shear force is a less studied aspect of culled dairy cows meat production industry and the Ps groups studied were not totally homogenous in body condition (reflecting the real conditions prevailing in slaughter lines) the present results must be cautiously analysed. In 
mature animals, the muscle collagen characteristics are already determined, in which differences in tenderness are more likely to be due to technical procedures applied on carcasses processing (chilling regime and aging rate and extension) rather than to pre-slaughter dietary or production status conditions per se (Minchin et al., 2009, Rider Sell, Mikel, Xiong, \& Behrends, 2004).

When the results of the two muscles were pooled together, meat of dried-off population slaughtered directly had a lower SF overall mean value $(51.90 \mathrm{~N})$ than that of lactating cows $(60.88 \mathrm{~N})(P<0.001)$. Lactation is a singular physiological state associated with considerable metabolic adaptations regarding the energy balance, in order to facilitate milk production. In high production dairy cows that adaptation will give carcasses with reduced dressing out percentages and lower fatness scores, but also an increase in muscular fibres size, having higher glycolytic potential (Khadem, Purchas, Morris, McCutcheon, \& Parker, 1995). These last modifications may improve muscle degradation and protein catabolism (Chibiza et al., 2008) making them more susceptible to early post-mortem tenderization (Lee et al., 2010) due to a higher calpain/calpastatin ratio (Ouali \& Talmant, 1990). This trend for an early tenderization was also observed in our study for the Gm muscle (68.36 N on day 2 for lactating cows vs. $70.44 \mathrm{~N}$ for dried-off cows) but it was not confirmed for LTL muscle (Table 3). Within the dried-off population, cows finished fed produced meat with higher mean tenderness than counterparts not finished (LTL $-43.90 \mathrm{~N}$ vs. $47.30 \mathrm{~N} ; \mathrm{Gm}-52.85 \mathrm{~N}$ vs. $57.61 \mathrm{~N}$ ) but differences were not significant. This last effect has not always been reported in other studies, with the results of Schnell, Belk, Tatum, Miller and Smith (1997) and Franco et al. (2009) showing shear force mean values in meat from finished fed animals for about 1 month to not being significantly different from controls or even showing greater shear force values. Besides any possible difference existing in protein turnover capacity between finished and not finished dried-off groups used in our study, the increase of subcutaneous fat deposition in carcasses and the higher mean IMF content in Gm muscle within the finishing fed animals may also be the source of its lower shear force mean value, by protecting against cold-shortening and increasing muscle tissue softness, respectively.

The rate of shear force decline for the lactating group differed between muscles. While in LTL muscle the mean values decreased gradually from a high maximum shear force of $74.62 \mathrm{~N}$ at day 2 up to a minimum value of $58.19 \mathrm{~N}$ at day 28 , representing a drop of about $30 \%$, in $\mathrm{Gm}$ muscle that evolution ranged between narrower limits (68.36 N and $59.46 \mathrm{~N}$, respectively, representing $13.0 \%$ of shear force decline). Both, the lower initial mean shear force value and the apparent lack of tenderization observed in Gm within the lactating group could apparently be related to a greater incidence of heat-shortened samples. Such occurrence would promote a higher initial activity of the enzyme systems involved in post-mortem proteolysis but also their greater denaturation as the time post-mortem extended. This hypothesis was not confirmed, since the number of Gm samples having a early rate of $\mathrm{pH}$ fall compactable with this phenomena (fast $\mathrm{pH}_{2}$ decline) among the lactating group (submitted for publication) was just 1 in a total of 16 evaluated.

Due to its anatomical location and poor dressing score of most of the carcasses, the LTL muscle within the lactating group would be more prone to cold shortening development, which would justify the increased mean shear force value at 2 and 7 days of aging and the incapacity for tenderizing latter on $(52.14 \mathrm{~N}$ after 42 days of aging, still representing a slightly tough meat). In fact, the lactating cows which LTL muscles showed slow rates of $\mathrm{pH}_{2}$ decline were extremely representative within this Ps group (5 in 7 samples evaluated), making expectable an average temperature/pH 6.0 relationship below the lower limit $\left(12^{\circ} \mathrm{C}\right)$ of the ideal window for quality (Hopkins, Ponnampalam, van de Ven, \& Warner, 2014). The different evolution of SF between muscles could still be accounted to a reduced intervention of the enzymes specific inhibitors in Gm muscle tenderization process (Sazili, Lee, Parr, Sensky, Bardsley, \& Buttery, 2003, Therkildsen, Stolzenbach, \& Byrne, 2011).

The retail packing industry needs to work with meat having WB mean shear force around $40 \mathrm{~N}$, or less, for good consumer satisfaction at home (Huffman, Miller, Hoover, Wu, Brittin, \& Ramsey, 1996), with this level rising up to $50 \mathrm{~N}$ in restaurant environment (Miller, Hoover, Cook, Guerra, Huffman, \& Tinney, 1995). To reach such shear force condition, meat from cull dairy cows slaughtered at S. Miguel, Azores, required to be aged, in average, at least for 14 days.

\subsection{Sensory Attributes}

Main effects and those resulting from Ps*At, $\mathrm{M}^{*} \mathrm{Ps}$ and $\mathrm{M}^{*} \mathrm{At}$ interactions were significant for all sensory attributes evaluated, excepting that from $\mathrm{M}^{*} \mathrm{At}$ for juiciness $(\mathrm{P}=0.168)$. $\mathrm{Ps} * \mathrm{At} * \mathrm{M}$ failed any significant effect on meat sensorial characteristics (Table 4).

When the meat tenderness of lactating vs. dried-off cows was compared, it expressed the same overall trend as referred for shear force evaluation, with both Ps not being different $(\mathrm{P}>0.05)$ for the Gm samples while the former Ps received significantly lower scores than the dried-off counterparts for the LTL muscle. 
Diverging of the shear force findings, the LTL overall mean tenderness of dried-off cows directly slaughtered was perceived as significantly improved than that of finished fed counterparts. It is worth noting that such better scoring was repeatedly assigned along the entire aging protocol, even when the differences in the mean shear force between both Ps reached almost $10 \mathrm{~N}$ (42 days). Meat tenderness is a function of production, processing and cooking methods used to prepare meat for consumption.

Table 4. Effects of production status, muscle type and aging time on sensorial attributes of meat (Gm and LTL muscles) of cull dairy cows

\begin{tabular}{|c|c|c|c|c|c|c|c|c|c|c|c|c|c|c|c|c|}
\hline & & & $\mathrm{Gm}$ & & & LTL & & & & $P$ values & & & & & & \\
\hline & $\begin{array}{c}\text { Aging } \\
\text { time } \\
\text { (days) }\end{array}$ & Lactating & Dried-off & Flushing & Lactating & Dried-off & Flushing & $\begin{array}{c}\text { Overall } \\
\text { mean }(A t)\end{array}$ & SE & $\begin{array}{l}\text { Production } \\
\text { status }(\mathrm{Ps})\end{array}$ & $\begin{array}{l}\text { Aging time } \\
\text { (At) }\end{array}$ & $\begin{array}{l}\text { Muscle } \\
\text { (M) }\end{array}$ & Ps*At & $\mathrm{M}^{*} \mathrm{Ps}$ & $\mathrm{M}^{*} \mathrm{At}$ & $\mathrm{P}_{3}^{*} \mathrm{At}^{*} \mathrm{M}$ \\
\hline \multirow{5}{*}{ Juiciness } & 2 & 5.88 & 5.70 & 5.73 & 5.40 & 5.48 & 5.52 & $5.62^{a}$ & \multirow{5}{*}{0.10} & \multirow{5}{*}{$<0.004$} & \multirow{5}{*}{$<0.001$} & \multirow{5}{*}{$<0.001$} & \multirow{5}{*}{0.007} & \multirow{5}{*}{$<0.001$} & \multirow{5}{*}{0.168} & \multirow{5}{*}{0.070} \\
\hline & 7 & 5.54 & 5.47 & 5.68 & 5.19 & 5.34 & 5.26 & $5.41^{b c}$ & & & & & & & & \\
\hline & 14 & 5.92 & 5.92 & 5.23 & 5.42 & 5.79 & 5.48 & $5.62^{a}$ & & & & & & & & \\
\hline & 28 & 5.58 & 5.70 & 5.55 & 5.45 & 5.90 & 5.27 & $5.58^{a b}$ & & & & & & & & \\
\hline & $\begin{array}{c}42 \\
n\left(F s^{*} M\right)\end{array}$ & $\begin{array}{c}5.61 \\
5.70^{a}\end{array}$ & $\begin{array}{c}4.99 \\
5.93^{\text {abc }}\end{array}$ & $\begin{array}{c}5.13 \\
5.48^{\text {bcd }}\end{array}$ & $\begin{array}{r}5.18 \\
5.32^{c d}\end{array}$ & $\begin{array}{c}5.46 \\
5.61^{a b}\end{array}$ & $\begin{array}{c}5.05 \\
5.29^{d}\end{array}$ & $5.24^{\circ}$ & & & & & & & & \\
\hline \multirow{5}{*}{ Tenderness } & 2 & 5.19 & 4.99 & 4.80 & 4.59 & 4.94 & 4.63 & $4.84^{e}$ & \multirow{6}{*}{0.10} & \multirow{6}{*}{$<0.001$} & \multirow{6}{*}{$<0.001$} & \multirow{6}{*}{0.034} & \multirow{6}{*}{0.014} & \multirow{6}{*}{0.014} & \multirow{6}{*}{0.019} & \multirow{6}{*}{0.512} \\
\hline & 7 & 5.47 & 5.51 & 5.44 & 4.59 & 5.61 & 5.42 & $5.34^{d}$ & & & & & & & & \\
\hline & 14 & 5.88 & 6.18 & 5.58 & 5.44 & 6.19 & 5.72 & $5.83^{\circ}$ & & & & & & & & \\
\hline & 28 & 6.19 & 6.26 & 5.80 & 5.60 & 6.44 & 6.27 & $6.09^{b}$ & & & & & & & & \\
\hline & 42 & 6.22 & 6.22 & 6.30 & 5.90 & 6.74 & 6.49 & $6.31^{a}$ & & & & & & & & \\
\hline Overall mear & $n\left(F s^{*} M\right)$ & $5.78^{a b}$ & $5.83^{a b}$ & $5.61^{b}$ & $5.22^{c}$ & $5.99^{a}$ & $5.67^{b}$ & & & & & & & & & \\
\hline \multirow{5}{*}{ Flavour } & 2 & 5.24 & 5.11 & 5.24 & 4.66 & 4.69 & 4.74 & $4.95^{\circ}$ & \multirow{6}{*}{0.10} & \multirow{6}{*}{$<0.001$} & \multirow{6}{*}{$<0.001$} & \multirow{6}{*}{$<0.001$} & \multirow{6}{*}{$<0.001$} & \multirow{6}{*}{0.003} & \multirow{6}{*}{$<0.001$} & \multirow{6}{*}{0.187} \\
\hline & 7 & 5.34 & 5.47 & 5.26 & 4.83 & 4.86 & 5.06 & $5.14^{d}$ & & & & & & & & \\
\hline & 14 & 5.51 & 5.55 & 5.31 & 5.19 & 5.31 & 5.09 & $5.33^{\circ}$ & & & & & & & & \\
\hline & 28 & 5.80 & 5.90 & 5.59 & 5.48 & 6.33 & 5.92 & $5.83^{b}$ & & & & & & & & \\
\hline & 42 & 6.38 & 7.29 & 6.56 & 6.16 & 7.34 & 6.96 & $6.78^{a}$ & & & & & & & & \\
\hline Overall meas & $n(P s * M)$ & $5.65^{b}$ & $5.87^{a}$ & $5.59^{b}$ & $5.27^{\circ}$ & $5.71^{a b}$ & $5.53^{b}$ & & & & & & & & & \\
\hline
\end{tabular}

Sensory scores for juiciness, tenderness and flavor: 1=extremely low in intensity; $8=$ extremely high in intensity; Within each trait, overall means $(P s * M)$ and overall means $(A t)$ with different letters are significantly different. $\mathrm{SE}=$ Standard error.

Although objective tenderness (e.g. shear force) is cheaper, it has also the disadvantage of being a simplistic one dimensional measure of a complex set of interactions, which occur when cooked meat is chewed and masticated in the mouth (Thompson, 2002). Also according to Perry, Thompson, Hwang, Butchers and Egan (2001), shear force is a useful indicator of sensory tenderness, but it does not account for all the improvements in sensory scores when meat is aged. Despite these disagreements, both meats were, in average, scored as acceptably tender.

The meat of lactating cows, irrespective of the muscle that it came from, obtained significantly lower mean scores in flavor than that of dried-off counterparts directly slaughtered. This trend was also seen in relation to juiciness within the LTL muscle group, but this Ps condition had the highest overall mean value in the Gm muscle, with differences being significant in relation to the dried-off flushing finished cows but not to those directly slaughtered.

Regarding juiciness and flavor, meat from not finished fed dried-off cows was also perceived as having higher quality than that of finished fed dried-off cows. The meat of lactating cows reached an intermediate position in juiciness (5.52), not differing from the other Ps conditions, whereas it was the least scored (5.46) concerning the flavor but not significantly different from that obtained from the finished fed cows.

Surprisingly, considering its lower current commercial added value, the sensory quality of Gm samples was considered superior, when compared to the LTL muscle (5.74 vs. 5.63 - tenderness; 5.57 vs. 5.41 - juiciness; 5.71 vs. 5.50 - flavor intensity, calculated from Table 4). Despite these differences, the meat from both muscles received mean scores indicating good overall eating quality. Expectably, the aging of meat improved significantly the tenderness and flavor attributes and, on the contrary, probably due to the increased purge losses (submitted for publication), tended to affect negatively the perceived juiciness.

Along with the relevance of a good sensory tenderness, minimizing the variation of meat pieces sent to retail is also a key goal for the meat industry. The natural aging of meat is a known crucial step in meat processing to achieve that purpose. In relation to LTL muscle, the number of sub-samples classified as tender and very/extremely tender increased substantially after 14 days of aging, reaching $59 \%$ and $16 \%$, respectively, with those perceived as still unacceptably tough being reduced to $6 \%$. On the other hand, aging for 28 days still promoted a reduction of tough samples to $3 \%$, increasing at the same percentage those scored as slightly tender and adding more $9 \%$ of samples scored as deeply/extremely tender. The percentage of LTL samples judged as tough decreased from $44 \%$ after 2 days aging to $0 \%$ after 42 days aging, while the percentage evaluated as very 
or extremely tender increased from 3\% to $47 \%$. The corresponding changes in Gm muscle suffered a decrease from $22 \%$ to $0 \%$ and an increase from $3 \%$ to $28 \%$, respectively. The best scores given to Gm muscles aged for short periods (tough samples $-22 \%$ vs. $44 \%$ after 2 days of aging; $9 \%$ vs. $19 \%$ after 7 days of aging; $3 \%$ vs. $6 \%$ after 14 days of aging) may probably be associated, among other reasons, to the higher local temperature in the early stages of the chilling process (less exposed to cooling than the LTL), which would speed up the enzymatic mechanisms of tenderization.

\section{Conclusions}

Whatever their production status, aged meat of cull dairy cows from LTL and Gm muscles presented quality attributes fulfilling, in average, expectations of retailing stakeholders and almost entire consumers satisfaction. Dried-off cows, comparatively to those still lactating, gave meat bearing better color attributes, lower shear force and superior sensory quality. The finishing feeding period carried out under the conditions assayed in the present study, did not enhance most quality traits evaluated, in comparison with standards evidenced by dried-off animals directly slaughtered. An aging time of 14 days seems to represent the best economical and commercial commitment for the meat industry working with mature dairy cows at S. Miguel-Azores, allowing to achieve, consistently, good or very good retailing and eating quality attributes.

\section{Acknowledgements}

This work was funded by the Azores Operational Programme for Convergence - PROCONVERGENCIA (Seproqual-inovação project).

\section{References}

Bekhit, A. E. D., Geesink, G. H., Ilian, M. A., Morton, J. D., \& Bickerstaffe, R. (2003). The effects of natural antioxidants on oxidative processes and metmyoglobin reducing activity in beef paties. Food Chemistry, 81, 175-187. http://dx.doi.org/10.1016/0309-1740(90)90019-3

Bruce, H. L., Stark, J. L., \& Beilken, S. L. (2004). The effects of finishing diet and postmortem ageing on the eating quality of the M. longissimus thoracis of electrically stimulated Brahman steer carcasses. Meat Science, 67, 261-268. http://dx.doi.org/10.1016/j.meatsci2003.10.014

Chibiza, G. E., Gozho, G. N., Van Kessel, A. G., Olkowski, A. A., \& Mutsvangwa, T. (2008). Effects of peripartum propylene glycol supplementation on nitrogen metabolism, body composition and gene expression for the major protein degradation pathways in skeletal muscle in dairy cows. Journal Dairy Science 91, 3512-3527. http://dx.doi.org/10.3168/jds.2007-0920.

Cranwell CD, Unruh JA, Brethour JR, Simms DD (1996) Influence of steroid implants and concentrate feeding on cacass and longissimus muscle sensory and collagen characteristics of cull beef cows. Journal of Animal Science, 74, 1777-1783. http://dx.doi.org//1996.7481770x.

Dikeman, M. E., Pollak, E. J., Zhang, Z., Moser, D. W., Gill, C. A., \& Dressler, E. A. (2005). Phenotypic ranges and relationships among carcass and meat palatability traits for fourteen cattle breeds and heritabilities and expected progeny differences for Warner-Bratzler shear-force in three beef cattle breeds. Journal of Animal Science, 83, 2461-2467.

Fishell, V. K., Aberle, E. D., Judge, M. D., \& Perry, T. W. (1985). Palatability and muscle properties of beef as influenced by pré slaughter growth rate. Journal of Animal Science, 61, 151-157.

Folch, J., Lees, M., \& Stanley, G. H. S. (1957). A simple method for the isolation and purification of total lipids from animal tissues. Journal of Biological Chemistry, 226, 427-509.

Franco, D., Bispo, E., González, L., Vázquez, J. A., \& Moreno, T. (2009). Effect of finishing and ageing time on quality attributes of loin from the meat of Holstein-Fresian cull cows. Meat Science, 83, 484-491. http://dx.doi.org/10.1016/j.meatsci.2009.06.030

Graham, W. C., \& Price, M. A. (1982). Feedlot performance and carcass composition of cull cows of different ages. Canadian Journal of Animal Science, 62, 845-854. http://dx.doi.org/10.4141/cjas82-102.

Gray, T. S. (2008). The breakdown of skeletal muscle in dairy cows during peak lactation. MS Thesis. Waikato University, New Zealand. Retrieved from http://researchcommons.waikato.ac.nz/bitstream/handle/10289/2249/thesis.pdf

Hopkins, D. L., Ponnampalam, E. N., van de Ven, R. J., \& Warner, R. D. (2014). The effect of pH decline rate on the meat and eating quality of beef carcasses. Animal Production Science, 54, 407-413.

Hornsey, H. C. (1956). The colour of cooked cured pork. I. Estimation of the nitric oxide-haen pigments. Journal 
of the Science of Food and Agriculture, 7, 534-540. http://dx.doi.org/10.1002/jsfa.2740070804

Huffman, K. L., Miller, N. F., Hoover, L. C., Wu, C. K., Brittin, H. C., \& Ramsey, C. B. (1996). Effect of beef tenderness on consumer satisfaction with steaks consumed in the home and restaurant. Journal of Animal Science, 74, 91-97.

JMP. (2010). JMP The statistical software. Cary, NC: SAS Institute, Inc.

Khadem, A. A., Purchas, R. W., Morris, S. T., McCutcheon, S. N., \& Parker, W. J. (1995). Carcass and meat quality characteristics of pasture-fed unbred and once-bred HerefordxFrisien heifers. New Zealand Journal of Agricultural Research, 38, 187-196. http://dx.doi.org/10.1080/00288233.1995.9513118

Koohmaraie, M. (1996). Biochemical factors regulating the toughening and tenderization process of meat. Meat Science, 43, S193-S201. http://www.ars.usda.gov/SP2UserFiles/Place/30400510/199643S193.pdf

Lee, S. H., Joo, S. T., \& Ryu, Y. C. (2010). Skeletal muscle fiber type and myofibrillar proteins in relation to meat quality. Meat Science, 86, 166-170. http://dx.10.1016/j.meatsci.2010.04.040

Malterre, C., Robelin, J., Agabriel, J., \& Bordes, P. (1989). Engraissement des vaches de réforme de race Limousine. INRA Productions Animales, 2, 325-334.

Mancini, R. A., Hunt, M. C., Kim, Y. B., \& Lawrence, T. E. (2004). How does lactate-enhancement stabilize beef colour? In Proceedings of 50th International Congresso f Meat Science and Technology, 8-13, August, Helsinki, Finland.

Mancini, R. A., \& Hunt, M. C. (2005). Current research in meat color. Meat Science, 71, 100-121. http://dx.doi.org/10.1016/j.meatsci.2005.03.003

Matulis, R. J., McKeith, F. K., Faulkner, D. B., Berger, L. L., \& George, P. (1987). Growth and carcass characteristics of cull cows after different times-on-feed. Journal of Animal Science, 65, 669-674.

Miller, M. F., Cross, H. R., Crouse, J. D., Jenkins, T. G. (1987). Effect of feed energy intake on collagen characteristics and muscle quality of mature cows. Meat Science, 21, 287-294. http://dx.doi.org/10.1016/0309-1740(87)90065-9

Miller, M. F., Hoover, L. C., Cook, K. D., Guerra, A. L., Huffman, K. L., \& Tinney, K. S. (1995). Consumer acceptability of beef steak tenderness in the home and restaurant. Journal of Food Science, 60, 963-965. http://dx.doi.org/10.1111/j.1365-2621.1995.tb06271.x

Minchin, W., Buckley, F., Kenny, D. A., Monahan, F. J., Shalloo, L., \& O’Donovan, M. (2009). Effect of grass silage and concentrate based finishing strategies on cull dairy cow performance, carcass and meat quality characteristics. Meat Science, 81, 93-101. http://dx.doi.org/10.1016/j.meatsci.2008.07.001

Muir, P. D., Smith, N. B., Wallace, G. J., Cruickshank, G. J., \& Smith, D. R. (1998). The effect of short term grain feeding on live-weight gain and beef quality. New Zealand Journal of Agricultural Research, 41, 517-526. http://dx.doi.org/10.1080/00288233.1998.9513334

Nour, A. Y. M., Thonney, M. L., Stouffer, J. R., \& White, W. R. C. (1983). Changes in carcass weight and characteristics with increasing weight of large and small cattle. Journal of Animal Science, 57, 1154-1165. http://jas.fass.org/content/57/5/1154.

Ouali, A., \& Talmant, A. (1990). Calpains and calpastatin distribution in bovine, porcine and ovine skeletal-muscles. Meat Science, 28, 331-348. http://dx.doi.org/10.1016/0309-1740(90)90047-A

Perry, D., Thompson, J. M., Hwang, I. H., Butchers, A., \& Egan, A. F. (2001). Relationship between objective measurements and taste panel assessment of beef quality. Australian Journal of Experimental Agriculture, 41, 981-989. http://dx.doi.org/10.1071/EA00023

Price, M. A., \& Berg, R. T. (1981). On the consequences and economics of feeding grain ad libitum to culled beef cows. Canadian Journal of Animal Science, 61, 105-111. http://dx.doi.org/10.4141/cjas81-015

Regulation (EC) $\mathrm{N}^{\circ} 103 / 2006$ of the European Commission of the 20 January, 2006 adopting additional provisions for the application of the community scale for the classification of carcasses of adult bovine animals.

Rider, S. N., Mikel, W. B., Xiong, Y. L., \& Behrends, J. M. (2004). Viatamin D3 supplementation of cull cows: effects on longissimus and semitendinosus muscle tenderness. Journal of Dairy Science, 82, 225-230. http://dx.doi.org//2004.821225x

Roseiro, L. C., Santos, C., Gonçalves, H., Moniz, C., Afonso, I., Tavares, M., \& da Ponte, D. J. B. (2014). 
Concentration of antioxidants in two muscles of mature dairy cows from Azores. Meat Science, 96, 870-875. http://dx.doi.org/10.1016/j.meatsci.2013.09.005

Sawyer, J. E., Mathis, C. P., \& Davis, B. (2004). Effects of feeding strategy and age on live animal performance, carcass characteristics and economics of short-term feeding programs for culled beef cows. Journal of Animal Science, 82, 3646-3653. http://dx.doi.org//2004.82123646x

Sazili, A. Q., Lee, G. K., Parr, T., Sensky, P. L., Bardsley, R. G., \& Buttery, P. J. (2003). The effect of altered growth rates on the calpain proteolytic system and meat tenderness in cattle. Meat Science, 66, 195-201. http://dx.doi.org/10.1016/S0309-1740(03)00091-3

Schnell, T. D., Belk, K. E., Tatum, J. D., Miller, R. K., \& Smith, G. C. (1997). Performance, carcass and palatability traits for cull cows fed high-energy concentrate diets for $0,14,28,42$ or 56 days. Journal of Animal Science, 75, 1195-12302.

Schaefer, D. M. (2005). Yield and quality of Holstein beef. In Managing and Marketing Quality Holstein Steers Conf. 323-333.

Sentandreu, M. A., Coulis, G., \& Ouali, A. (2002). Role of muscle endopeptidases and their inhibitors in meat tenderness. Trends in Food Science \& Technology, 13, 200-221. http://dx.doi.org/10.1016/S0924-2244(02)00188-7

Singh, P., Wani, A. A., Saengerlaub, S., \& Langowski, H. C. (2011). Understanding critical factors for the quality and shelf-life of MAP fresh meat: a review. Critical Reviwes in Food Science and Nutrition, 51, 146-177. http://dx.doi.org/10.1080/10408390903531384

Tang, J., Faustman, C., Lee, S., \& Hoagland, T. A. (2003). Effect of glutathione on oxymyoglobin oxidation. Journal of Agricultural and Food Chemistry, 51, 1691-1695. http://dx.doi.org/10.1021/jf025924f

Therkildsen, M., Stolzenbach, S., \& Byrne, D. V. (2011). Sensory profiling of textural properties of meat from dairy cows exposed to a compensatory finishing strategy. Meat Science, 87, 73-80. http://dx.doi.org/10.1016/j.meatsci.2010.09.005

Thompson, J. (2002). Managing meat tenderness. Meat Science, 62, 295-308. http://dx.doi.org/10.1016/S0309-1740(02)00126-2.

Vestergaard, M., Oksberg, N., \& Henckel, P. (2000). Influence of feeding intensity, grazing and finishing feeding on muscle fibre characteristics and meat colour of semitendinosus, longissimus dorsi and supraspinatus muscles of young bulls. Meat Science, 52, 177-185. http://dx.doi.org/10.1016/S0309-1740(99)00097-2

Vestergaard, M., Madsen, N. T., Bligaard, H. B., Bredahl, L., Rasmussen, P. T., \& Andersen, H. R. (2007). Consequences of two or four months of finishing feeding of culled dry dairy cows on carcass characteristics and technological and sensory meat quality. Meat Science, 76, 635-643. http://dx.doi.org/10.1016/j.meatsci.2007.02.001

Wheeler, T. L., Cundiff, L. V., Koch, R. M., \& Crouse, J. D. (1996). Characterization of biological types of cattle (Cycle IV.): carcass traits and longissimus palatability. Journal of Animal Science, 74, 1023-1035.

Wheeler, T. L., Cundiff, L. V., Shackelford, S. D., \& Koohmaraie, M. (2005). Characterization of biological types of cattle (Cycle VII.): carcass, yield and longissimus palatability traits. Journal of Animal Science, 83, 196-207.

\section{Copyrights}

Copyright for this article is retained by the author(s), with first publication rights granted to the journal.

This is an open-access article distributed under the terms and conditions of the Creative Commons Attribution license (http://creativecommons.org/licenses/by/3.0/). 